\title{
People and Pets in Besieged Leningrad
}

\author{
V.L.Piankevich, O. Yu.Plenkov, T.E. Sokhor
}

For citation: Piankevich V.L., Plenkov O. Yu., Sokhor T.E. People and Pets in Besieged Leningrad. Vestnik of Saint Petersburg University. History, 2020, vol. 65, iss. 1, pp. 158-174.

https://doi.org/10.21638/11701/spbu02.2020.109

The article provides an insight into the relations between people and pets during the siege of Leningrad. Mass historical consciousness features different, sometimes distorted ideas and myths about this topic. The issue of eating pets was a taboo in the official discourse and historiography. The relationship between people and pets was covered by memoirs and notes of the siege survivors and by scholars. However, the authors are not aware of any studies focusing specifically on this topic. Based on diaries and letters of the siege period and later memoirs, the article deals with the relations between people and pets in the tragic circumstances and contemporary myths about the past. Most of the dramatic accounts, provided by the survivors, date back to the first autumn of the siege and the winter of 1941-1942. City authorities and law-enforcement bodies had to turn a blind eye to people eating pets and did not comment on it. Starvation frequently forced people to engage in the bizarre and previously unthinkable activity - pet hunting. City-dwellers primarily tried to feed this high-caloric 'delicacy' to children, often concealing its true nature. Laboratory animals also used to save lives. Pets were traded at the improvised markets. Eating pets could be life-saving, but didn't guarantee the survival. The popular legend about the delivery of cats from eastern parts of the country, which is still circulating, was never documented. However, the persistence of this myth reflects the wish of the survivors to comprehend their terrible experience and overcome the trauma.

Keywords: Great Patriotic War, siege of Leningrad, pets, social memory, social history of war, history of everyday life.

Vladimir L.Piankievich - Doctor in History, Professor, St. Petersburg State University, 7-9, Universitetskaia nab., St. Petersburg, 199034, Russian Federation; v.pyankevich@spbu.ru

Владимир Леонидович Пянкевич - д-р ист. наук, проф., Санкт-Петербургский государственный университет, Российская Федерация, 199034, Санкт-Петербург, Университетская наб., 7-9; v.pyankevich@spbu.ru

Oleg Yu. Plenkov - Doctor in History, Professor, St. Petersburg State University, 7-9, Universitetskaia nab., St. Petersburg, 199034, Russian Federation; o.plenkov@spbu.ru

Олег Юрьевич Пленков - д-р ист. наук, проф., Санкт-Петербургский государственный университет, Российская Федерация, 199034, Санкт-Петербург, Университетская наб., 7-9; o.plenkov@spb.ru

Tatiana E. Sokhor - laboratory engineer, St. Petersburg State University, 7-9, Universitetskaia nab., St. Petersburg, 199034, Russian Federation; t.sohor@spbu.ru

Татьяна Евгеньевна Сохор - инженер-лаборант, Санкт-Петербургский государственный университет, Российская Федерация, 199034, Санкт-Петербург, Университетская наб., 7-9; t.sohor@spbu.ru

(c) Санкт-Петербургский государственный университет, 2020 


\section{Люди и домашние животные в блокадном Ленинграде}

\section{В. Л. Пянкевич, О. Ю. Пленков, Т. Е. Сохор}

Для цитирования: Piankevich V.L., Plenkov O. Yu., Sokhor T.E. People and Pets in Besieged Leningrad // Вестник Санкт-Петербургского университета. История. 2020. Т.65. Вып. 1. С. 158-174. https://doi.org/10.21638/11701/spbu02.2020.109

В статье рассматривается проблема отношения людей к домашним животным в условиях блокады Ленинграда. В массовом историческом сознании существуют разные, в том числе искаженные, представления, легенды о домашних животных осажденного города. Поедание домашних животных было табуировано в официальном дискурсе и историографии. Тема взаимоотношений человека и домашнего животного получила отражение в литературных текстах, базирующихся на наблюдениях или свидетельствах блокадников, упоминается в научной литературе. Однако авторам неизвестны какие-либо специальные исследования, посвященные этой теме и соответствующие научные публикации. На основе свидетельств из документов блокадного и более позднего времени в статье показаны явления и процессы, связанные с взаимоотношениями людей и животных в условиях катастрофы осады, истоки современных мифов о прошлом. Источниковой базой публикации послужили свидетельства из дневников, писем периода блокады, воспоминаний, появившихся позднее. Абсолютное большинство драматических свидетельств блокадников о домашних животных относятся к первой блокадной осени и зиме 1941-1942 гг. Руководство города, правоохранительных органов было вынуждено закрывать глаза, не реагировать на поедание домашних животных. Нередко голод толкал к прежде странному и невозможному - охоте на домашних животных. Высококалорийным «деликатесом», нередко скрывая его происхождение, блокадники стремились накормить в первую очередь детей. Спасением для людей могли стать подопытные животные. Домашних животных стали продавать, покупать и обменивать на многочисленных стихийных рынках. Поедание домашних питомцев могло спасти, но не было гарантией выживания. Еще во время войны появилась широко распространенная и сохраняющаяся по сию пору легенда о завозе в Ленинград кошек, отловленных на востоке страны, которая не имеет документального подтверждения. Вместе с тем устойчивость этого мифа связана со стремлением многих блокадников осмыслить пережитый ужас, преодолеть травму блокады.

Ключевые слова: Великая Отечественная война, блокада Ленинграда, домашние животные, социальная память, социальная история войны, история повседневности.

"The suffering of people and animals in Russia is immeasurable." Leo Tolstoi

The destiny of pets in besieged Leningrad has entered the orbit of public discourse, in particular, mass media fairly recently. A lot of information concerning this issue, often distorted and unreliable, is available on the internet.

A chapter from the "Book of siege" by A. Adamovich and D. Granin, based on the memoirs of the survivors, features the relations between human beings and pets ${ }^{1}$. Moreover, this topic is covered by other works of literature, drawing on the memories and notes of the survivals ${ }^{2}$. Scholarship mentions starving people hunting cats and

${ }^{1}$ Adamovich A., Granin D. Blokadnaia kniga. St. Petersburg, 2013. P. 183-196.

2 Abramov F. A. Potomok Dzhima // Abramov F. A. V SMERSHe: zapiski kontrrazvedchika. Moscow, 2018. P.73-80; Foniakova E. Ragu iz Barsika // Foniakova E. Khleb toi zimy: povest'. St. Petersburg; Moscow, 2016. P. 181-185; Rozen A. G. Fram // Rozen A. G. Pochti vsya zhizn’: Povesti i rasskazy. Leningrad, 1978. 
$\operatorname{dogs}^{3}$. A. R. Dzeniskevich touched upon this issue in his article about cannibalism in besieged Leningrad ${ }^{4}$; S. V. Iarov also mentioned the 'customary practice' of eating cat and dog meat 'on the threshold of death' ${ }^{5}$. However, the authors are not aware of any studies or scholarly publications focused on this particular topic.

The issues of eating pets and cannibalism at the time of the siege were tabooed in the official discourse and historiography. The disastrous situation with food supplies in the besieged city whose dwellers were compelled to eat some unthinkable substitutes was to be kept back from the 'big land' (the territory of the Soviet Union which was not occupied). In order to avoid the censorship of the war time, the people of Leningrad had to resort to different tricks. Thus, quoting the sociologist and theatre critic V.N. Dmitrievsky, "in November the second floor neighbors sent a wire to their relatives: 'We are doing just fine having eaten our calf Arka. The relatives managed to send a parcel with some supplies: they remembered Arka, a Doberman hound..."6 M. U. Konisskaia, a painter from Leningrad, wrote in a letter (December 23, 1941): "Regrettably, I have to inform you that the chicken (in fact - a cat. - Editor L. B.) which you left in my care - Gorzhetka (Boa) by name was butchered and eaten. It was the last one; we had eaten 26 chickens (cats. Editor L.B.) before and lived on their meat for six weeks. Now only my father's favorite goat (the dog. - Editor L. B.) is left - Irma, but we will keep it as a last resort, in case evacuation may be. Alas, sentiments are not needed during the war, and nobody thinks about them here..."7

The popular topic of pets in the besieged city, their lives and deaths, has been largely mythologized in the collective consciousness. Meanwhile, the analysis of the nature and characteristic features of the relationship between pets and their owners and the habits of pets can help to define the survival strategies, self-identification mechanisms and the formation of bonds in the situation of emergency.

The article is based on the following sources: the letters and diaries of the siege period, and the memoirs which were unveiled later. The overwhelming majority of the records mentioning pets date back to the first autumn of the siege and the winter of 1941-1942. With time, these references would dwindle to nothing as the population decreased and there were hardly any animals left.

\section{'Nothing left, but the dreams'}

According to the Veterinary Department of St. Petersburg, 50 percent of St. Petersburg households currently have pets: approximately one million cats and three hundred thousand dogs. The city is also the habitat of stray cats and $\operatorname{dogs}^{8}$. Due to the smaller pop-

${ }^{3}$ Dzeniskevich A.R., Koval'chuk V.M., Sobolev G.L., Camutali A.N., Shishkin V.A. Nepokorennyi Leningrad: Kratkii ocherk istorii goroda v period Velikoi Otechestvennoi voiny. Leningrad, 1970.

${ }^{4}$ Dzeniskevich A.R. Banditizm (osobaia kategoriia) v blokirovannom Leningrade // Istoriia Peterburga. 2001. No.1. P. 48.

${ }^{5}$ Iarov S. V. "Povarennaia kniga" blokady // SSSR vo Vtoroi mirovoi voine: okkupatsiia, kholokost, stalinizm. Moscow, 2014. P. 260.

6 Dmitrievskii V.N. Zhizn'v epizodakh: [vospominaniia 1930s-1970s.]. St. Petersburg, 2011. P. 64.

7 Tri pis'ma iz blokady / Publikatsiia L. P. Beliakova // Istoriia Peterburga. 2006. No. 6. P. 77.

8 Obsuzhdaem proekt Deklaratsii obrashcheniia s zhivotnymi v Sankt-Peterburge // Upravlenie veterinarii Sankt-Peterburga. URL: https://www.gov.spb.ru/gov/otrasl/veter/news/135082/ (accessed: 15.12.2018). 
ulation figures, modest living standards and conditions, the number of pets in Leningrad before the war must have been lesser. Nevertheless, many people did keep pets, sometimes to replace their absent or deceased relatives. Having a pet could be a real recreation for the loners, for those who experienced communication problems, for the disabled and for families with children. Animals guarded houses and various objects and sites, hunted rodents etc.

Food shortages in the autumn of 1941 suggested the idea of eating cats and dogs to satisfy hunger. However, while some of the city dwellers just started thinking about this option, others turned out to be more decisive and smart. "When the siege started, many cats went missing... With time, my mother started looking around thinking about catching one, but could not bring herself to do this out of pity. When she finally made up her mind, they disappeared from the streets; there was nothing left, but the dreams. My mother used to lie down and regret that she had not brought herself to do it when it was still possible". These regrets not only concerned stray animals, but pets as well. "How stupid I was! We had two cats and a dog. They all have been snatched away..." wrote a resident of the city in November. "If only I had butchered and fried them, and had got some more and suspended (the meat) from the ceiling in a cold corridor, I would be able to cut off little morsels now..." ${ }^{10}$ In the same way at the 'threshold of death' many people blamed themselves for having been light-minded and impractical in contrast to other people, for not having built up a stock of food and prepared for the famine and siege ${ }^{11}$.

Within the first autumn of the siege pets disappeared from the courtyards of Leningrad, with residents at times exaggerating the swiftness of this process. "I remember sudden disappearance of cats, dogs and pigeons, although it was only early November"12. On the same day - November 29 - four residents of the besieged city would write in their diaries: "There are hardly any cats and dogs in the streets and courtyards - they all have been eaten. In the rubbish bins $\langle\ldots\rangle$ cats' skins with heads attached to them have been found" (A. I. Avgustyniuk) ${ }^{13}$. "There are no cats left" (A. A. Chernovsky) ${ }^{14}$. "Hungry stray cats, who used to hang about in abundance and whom my mother felt so sorry for, have disappeared completely of late" (S. K. Ostrovskaia) ${ }^{15}$. "Now not a single cat can be spotted anywhere"16.

The owners of missing cats and dogs were convinced that their pets had been caught and eaten. Stunned city residents wrote about the previously unthinkable practices with

${ }^{9}$ Koribskaia N. V. 871 den'. Moscow, 2010. P. 98.

10 "Zhestokoe ispytanie..." (dnevnik blokadnitsy) / Dnevniki blokadnykh zhitelei iz arkhiva O. F. Berggol'ts // Ezhegodnik Rukopisnogo otdela Pushkinskogo doma na 2014 god: Blokadnye dnevniki / eds T. S. Tsar'kova, N. A. Prozorova. St. Petersburg, 2015. P. 152.

11 See.: Piankevich V.L. Povedenie leningradtsev nakanune i v nachale blokady // Velikaia Otechestvennaia voina: pravda i vymysel: Sb. statei i vospominanii. Iss. 7 / comp. by V. A. Kutuzov. St. Petersburg, 2012. P. 66, 67.

12 Krymov V.D. Tiazheloe i radostnoe // Deti i blokada: vospominaniia, fragmenty dnevnikov, svidetel'stva ochevidtsev, dokumental'nye materialy. St. Petersburg, 2009. P. 131.

13 A. I. Avgustyniuk. Moi vospominaniia s momenta nachala Velikoi Otechestvennoi voiny do kontsa ee. 23 iiunia 1941g. - 9 maia 1945 g. // Tsentral'nyi gosudarstvennyi arkhiv istoriko-politicheskikh dokumentov Sankt-Peterburga (CGAIPD St. Petersburg). Fond 4000. Inventory 11. File 2. P. 13.

${ }^{14}$ Chernovskii Aleksei Alekseevich (senior research fellow of the City Museum). Dnevnik // TsGAIPD St. Petersburg. Fond 4000. Inventory 11. File 119. P. 32.

15 Ostrovskaya Sofiia Kazimirovna. Dnevnik // Otdel rukopisei Rossiiskoi natsional'noi biblioteki (OR RNB). Fond 1448. File 9. P. 125 back.

${ }^{16}$ Bolgova R. M. Blokadnaia khronika nashei sem'i // Deti i blokada... P. 82. 
disgust. Eating pets became a habitual and even advisable thing. "Eating cats and dogs was commented on as something normal and natural"17. "The people grew vicious and cruel, ate cats and dogs, and later on children started to go missing" ${ }^{18}$. A. R. Dzeniskevich also admitted this sequence of events. Analyzing the causes of such an appalling crime as cannibalism, he argued that the hunger "which killed people massively, also drove them insane, with mentally unstable people being the most susceptible"19. "Cats, dogs and pigeons were the first victims" 20 , continued the scholar.

According to most of the extant records, residents of the besieged city started eating both their own pets and pets of others in November-October 1941. A. A. Chernavsky, a research fellow in the City Museum of Leningrad, wrote on October 25: "Today the first cat has been eaten in Lesha's family"21. "People in Leningrad are starving - they eat cats and dogs", noted I. A. Savinov, an engineer, on November 17. "Cats have become a delicacy"22. Within the first winter of the siege pets vanished completely. "There are hardly any cats left: they have all been either put to sleep or snatched away and eaten", states a diary entry of M.S. Konopleva, a research fellow at the Hermitage, on December $11^{23}$. The next day Z.Z.Shnitnikova, an economist, stated: "All cats and dogs in the city have been finished off" 24 . Diaries, letters and memoirs of many other residents confirmed the same thing.

Animals like people died of starvation, cold and diseases. Cold winter, the absence of central heating in the houses and malnutrition did not leave the animals much of a chance to survive. Some owners put their pets to sleep at the onset of the siege, when the perspective of starvation became real. In London, when the Air Battle for England was about to start, many owners concerned about being unable to feed their pets, had them put down, and later when the danger was over, regretted it bitterly. In Germany, by contrast, pets were granted ration cards until the end of the war.

Residents of Leningrad sent their dogs to serve in the $\operatorname{army}^{25}$. Going to the front might also have been the only and most preferable way for the people to escape starvation. It is difficult to estimate the number of animals killed by the bombs and shells. The number of people who fell victim to bombs and shells accounts to less than 3 percent of all who, according to official records, starved to death during the siege ${ }^{26}$. It can be suggested that the casualties among the animals did not exceed the casualties among the people.

17 Sokolov A. M. Bitva za Leningrad i ee znachenie v Velikoi Otechestvennoi voine. St. Petersburg, 2005. P. 103.

18 Gritsenko G. A. "Sobirali pal'tsem voobrazhaemye kroshki..." // Leningradskoe blokadnoe bratstvo: vospominaniia uchastnikov oborony Leningrada i ego zhitelei. Nizhnii Novgorod, 2011. P. 27.

19 Dzeniskevich A. R. Banditizm... P. 48.

${ }^{20}$ Ibid.

${ }^{21}$ Chernovskii Aleksei Alekseevich (senior research fellow of the City Museum). Dnevnik // TsGAIPD. St. Petersburg. Fond 4000. Inventory 11. File 119. P. 16.

22 Savinkov Ivan Alekseevich. Dnevnik. 1941-1945 gg. // TsGAIPD. St. Petersburg. Fond 4000. Inventory 11. File 99. P. 11 back.

${ }^{23}$ Konopleva Mariia Sergeevna. V blokirovannom Leningrade (1941-1942 gg.). Zametki // OR RNB. Fond 368. File 2. P. 5.

${ }^{24}$ Blokadnyi dnevnik Z.Z. Shnitnikovoi: 2 sentiabria 1941 - 17 iiulia 1942 g. / comp. by R. B. Samofal // Voprosy istorii. 2009. No 5. P. 58.

25 Bobyr' S.L. Sistema voennogo sobakovodstva v Velikoi Otechestvennoi voine. 1941-1945 gg.: Istoricheskii aspekt // Dysha odnim dykhan'em: Voennye kinologi na fronte. St. Petersburg, 2015. P. 239.

${ }^{26}$ Leningrad v osade: Sbornik dokumentov o geroicheskoi oborone Leningrada v gody Velikoi Otechestvennoi voiny, 1941-1944. St. Petersburg, 1995. P. 573. 
The authorities, in fact, did not comment on the practice of eating pets although the policemen (militiamen) would anxiously report on the fact that the "lack of food made some residents eat cats and dogs, and cases of eating fallen animals have also been registered". However, soon enough the policemen dismissed the subject of pets being eaten by people in favor of other issues ${ }^{27}$. The experts from St. Petersburg argue that the city authorities must have ignored the situation, showing neither support nor disapproval of the people who ate cats and dogs to assuage their hunger ${ }^{28}$. However, sometimes punitive measures were taken. Thus, the report of UNKVD (Department of the Peoples' Commissariat of Internal Affairs) of Leningradskaia oblast' from November 28, 1941 on the living conditions of the population evacuated to Leningrad and its suburbs stated: "Poor nutrition makes some families starve. The Kukonins and Ryzhovs families, who live in the village of Lakhta, eat the meat of cats and dogs. In the evacuation centre in Toksovo a certain Zimushin from Krasnogvardeisk killed cats and dogs in the presence of local residents and passed their meet round for cooking. Zimushin has been arrested"29. Apparently, such a punishment was rather an exception to the rule. In general, the city authorities had to turn their back on such cases.

\section{'Why do they call it a kitty while it is still alive, and a rabbit when they eat it?'}

In the autumn of 1941, when animals became a desirable prey for many residents, the owners of cats and dogs were bombarded by relatives, friends and strangers with requests to give away their pets. "I was shell-shocked when Alia suddenly asked me: - 'Please, give me your Sarrka for Lida's sake!" " wrote in her diary on December 8 O. V. Sinkevich, a teacher. "I answered that Sarra was not mine but Marusia's, and we all loved her as a family member and to give her away to be eaten would be the worst form of betrayal. — 'But anyway there is nothing to eat, - it will starve to death. We have already eaten our cat. I beg you: for the sake of Lida.' I said I could not do this" ${ }^{30}$. Other residents also mentioned the same thing. Looking back on those days, E. Samoilovich recalls: "As the grasp of the siege became tougher, pets disappeared from flats. My mother and I were stalked by the people who begged persistently: 'Give us your dog, please, sell it! Our children are starving!' "31 C. V. Yarov comments on this and similar cases: the people who asked the owners to donate their cats would often refer to the hungry children - the value of the suggested present must have been so high that the most irrefutable arguments were required ${ }^{32}$.

The starvation made people very assertive and forced them to break conventional moral and ethical rules. There were those who dared to commit improper deeds. The historian and archivist G. A. Kniazev (the director of the Archive of the USSR Academy

27 Dzeniskevich A. R. Banditizm... P. 48.

${ }^{28}$ Koval'chuk V.M., Rupasov A.I., Chistikov A. N. Leningradtsy v gody voiny: adaptatsionnye praktiki // Adaptatsiia narodov i kul'tur k izmeneniiam prirodnoi sredy, sotsial'nym i tekhnogennym transformatsiiam. Moscow, 2010. P. 384.

${ }^{29}$ Leningrad v osade... P. 275.

30 Sinakevich Ol'ga Viktorovna. Dnevnik. Zima 1941-1942 gg. Leningrad, Kazakhstan // OR RNB. Fond 163. File 31. P. 53.

31 Tipikina E. Sluzhebnym sobakam pokhval'noe slovo: [Interv'iu s Elizavetoi Samoilovich] // Dysha odnim dykhan'em: Voennye kinologi na fronte. St. Petersburg, 2015. P. 179.

32 Iarov S. V. "Povarennaia kniga" blokady. P. 261. 
of Sciences) on March 13, 1942 gave an account of the events which had happened with the family who lived next door: "The other day a friend of theirs, a student, dropped in. He saw a cat and begged to give it to him... With great difficulty they managed to get rid of him... Poor women were terrified and are now concerned about him sneaking back to steal the cat" ${ }^{\prime \prime}$.

Those who committed thefts did not feel remorse. V.S. Kostrovitskaia, a choreographer, recalls how she and her fellow students of the Leningrad College of Choreography during the night watch used to lick clean the dishes of the cat which belonged to L. S. Targer, the acting director of the college. The starving woman made up her mind to steal the well-fed cat: "I put it in a basket and dragged home; en route it was screaming and trying to escape. The people turned back and stared at me and I saw not amazement, but envy in their eyes. A few people approached me asking apprehensively: 'Is there any chance you will sell it?' I have to share the cat with the Shostakoviches: the composer himself, his mother, sister and a 13-year old nephew Mitya. Those who butcher the cats usually take half of the meat as payment, so what will be there left for two families?" 34 The choreographer had no doubts that there was nothing wrong with stealing a fat cat of a well-nourished owner in order to feed the starving people.

Hunger often induced people to engage in the most unthinkable and despicable activity - pet hunting. On November 24, Z.Z. Shnitkova in her diary gave an account of her friend's experience in cat hunting: "My mother caught it and killed with a hammer; afterwards we cooked a stew" 35 . "Many people would chase cats and dogs, make soup"(November 29) ${ }^{36}$. The prospect of assuaging one's hunger was extremely tempting. Sometimes not only hunger, but one's family members urged people to go hunting: "Yadia, go, find some cat - we have already finished off ours," - asked the father of Ya.D. Smirnova not long before he died of starvation ${ }^{37}$.

Cat hunters were to be lucky and smart. "Sometimes I was lucky", recalled T. B. Bezladnova. "If I caught sight of a cat, I would chase and grab it, bring home and keep somewhere until dark. In the evening, when all the family members dropped off to sleep, I would wrap it into a bag and put it down with diethyl ether. After that I would skin the animal, carve the meat and next day serve this 'rabbit' to Mother, Shura and Irinka"38. O. I. Krestovsky recalls that he and his brother "had to eat 8 gaunt cats, having started with their own hunger-stricken cat and continuing with those caught in the basements (my brother was a good hunter, skillful with rabbit traps)" 39 . "It was a full-grown smart cat, which knew very well that falling into our hands would be a bad luck. We had been trying to catch it for ages, but to no avail, - so we gave in and called Mother. She got dressed and started coming down the stairs, pretending she did not care about the cat. It did not smell a rat, and Mother, passing by, quickly bent down and grabbed it by the scruff. Thank

33 Kniazev G. A. Dni velikikh ispytanii: dnevniki, 1941-1945. St. Petersburg, 2009. P. 539.

34 Kostrovitskaia Vera Sergeevna (1906-1979), artistka baleta, pedagog klassicheskogo tantsa. Vospominaniia o blokade // Tsentral'nyi gosudarstvennyi arkhiv literatury i iskusstva Sankt-Peterburga (TsGAIPD. St. Petersburg). Fond 157. Inventory 1. File 28. P. 8.

35 Blokadnyi dnevnik Z.Z. Shnitnikovoi... P. 58.

${ }^{36}$ Bolgova R. M. Blokadnaia khronika nashei sem'i... P. 82.

37 Vospominaniia o blokade = Wspomnienia o blokadzie / comp. by M. Budkevich. St. Petersburg, 2003. P. 58.

38 Deti voiny: 100 ocherkov-vospominanii liudei, detstvo i iunost' kotorykh byli opaleny Velikoi Otechestvennoi voinoi. St. Petersburg, 2014. P. 28.

39 Efimovskii E. Spasennyi Peterburg. St. Petersburg, 2010. P. 25. 
you, dear cats! You might have saved our lives" ${ }^{\text {" }}$. A war correspondent M. Ivin summed up in 1943: "Residents of Leningrad had eaten their pets, both cats and dogs, within the first months of the siege, and who knows how many people, barely alive and on the brink of starvation, owed their lives to the meat of these animals" 41 . It is difficult to say to what extent this practice contributed to the survival. Probably, in some cases it really did save lives, but obviously was not a cure-all. It should be also taken into consideration that not all residents were fit enough for hunting activities.

Some people justified their actions taking pride in the number of hunting "trophies". Others were ashamed of what they had to do. Even outside the besieged city people used to stick to old habits. Thus, M. Durnovo, the wife of the writer and poet D. Harms, featured the events after the evacuation from Leningrad, when she stayed in a rural house: "Suddenly I saw a cat! A living cat! I screamed at the top of my voice: "Hold it! Comrades, don't let it go!" and rolled off the top of the stove. I rushed after the cat to catch it, but it ran away, thank God. The hosts stared at me in horror" 42 .

Residents of the city primarily tried to feed this high-calorie 'delicacy' to children, often concealing its true nature, although elder kids somehow managed to find out the truth. Trying to save their children from starvation, many adults, especially women, refrained from eating this food but failed to hold this 'unwanted information' back from children. "My mother refused to eat them (cats) at first, but soon the hunger forced her to do this," recalled T. B. Bezladnova, "Once, at meal time, Ira put aside her plate and asked pensively with her head resting on her hands: 'Why do they always call it a kitty while it is still alive, and a rabbit when they eat it?' "43

Laboratory animals also turned out to be life-savers. As D.S. Likhachev wrote in his memoirs: "Hungry dogs were barking desperately in the courtyard of the Institute of Physiology (It is the meat of these dogs that saved the lives of many physiologists)" 44 . V.S. Kostrovitskaia's diary entry from November 1941 confirms this information: "All the stuff members of Pavlov Institute eat their laboratory dogs" 45 .

Purchase, sale and exchange of pets took place at numerous improvised markets. As objects in the process of goods exchange that most of the population could not do without, pets did not differ much from food substitutes and other commodities. "People used to buy cats more willingly, but dogs were also in demand", wrote M.C. Konopleva in her diary $^{46}$. "Once we bartered a mirror for a cat", recalls N. V. Kupriianova ${ }^{47}$. As in the case of purchasing a precious piece of bread or some grain from profiteers at an unthinkable price, residents of besieged Leningrad were equally happy when they managed to buy or barter a cat or a dog, and were equally devastated if the deal fell through. People not only enthused about the products they consumed to appease their hunger, but also marveled at the taste of them, exchanged exalted comments, grieved that there were no cats and dogs

40 Iakubovich E.D. Vospominaniia o blokade // Trudy Gosudarstvennogo muzeia istorii SanktPeterburga. Issue V: Materialy k istorii blokady Leningrada. St. Petersburg, 2000. P. 240.

${ }^{41}$ Ivin M. I veritsia s trudom // Neva. 1993. No.11. P. 265.

42 Glotser V.I. Marina Durnovo. Moi muzh Daniil Harms. Moscow, 2005. P. 131.

43 Deti voiny... P. 28.

${ }^{44}$ Likhachev D. S. Vospominaniia. St. Petersburg, 1999. P. 458.

45 Kostrovitskaia Vera Sergeevna (1906-1979), artistka baleta, pedagog klassicheskogo tantsa. Vospominaniia o blokade // CGALI St. Petersburg. Fond 157. Inventory 1. File 28. P. 5.

46 Konopleva Mariia Sergeevna. V blokirovannom Leningrade (1941-1942 gg.). Zametki // OR RNB. Fond 368. File 1. P. 188.

47 From a private archive of A. A. Dragunkina. 
around and dreamed of getting one. "How I wish I could get a nice juicy dog", confessed A. I. Avgustyniuk on November $30^{48}$.

Great demand for all eatable goods explained soaring prices for pets. "They eat cats in the city. $\langle\ldots\rangle$ Average price is - 40-60 rubles for a cat," wrote S. K. Ostrovskaia on November $29^{49}$. "They pay 50-60 rubles for a living cat (which can be eaten!)", noted M.S. Konopleva ${ }^{50}$. Due to dramatic food shortage, and the declining number of animals the prices escalated. "The owner of one cat has boasted today that he was offered $125 \mathrm{ru}$ bles for it", recorded I.D.Zelenskaia, an engineer ${ }^{51}$. However, this remark of the owner might have been prompted by the wish to demonstrate what a desirable resource he had in his possession. According to the German secret service, in late December 1941, the average cost of a cat was about 250 rubles; the dogs, which were scarce, were reported to be 300 rubles worth or more ${ }^{52}$.

Handbills offering to buy pets appeared in the city. E. I. Mirskaya wrote: "In the hardest winter of 1941-1942, at Sennoy market I saw a few men wearing tablets on the necks which stated: 'Want to buy a cat' or 'Want to buy a dog'"53. Such ads became a common sight.

Great demand for food and, respectively, for pets as a substitute for food gave rise to a great number of handwritten advertisements - evidence of the plight of residents. Realizing the doubtful effectiveness of such requests, many people, nevertheless, resorted to this method hoping to survive: "Here and there ads can be found on the fences: 'want to buy a dog, will pay 100 rubles' and an address",wrote V.S. Kostrovitsksaia in November. "It is very unlikely, though, that somebody will read the ad and come to this address. Everyone dreams of buying a dog for him/herself" 54. "Once, looking through purchase and sale ads, I came across one: 'Want to buy a good dog, an Alsatian. The engineer so-and-so.' Having read this, I grinned. What is the point of being so precise: why an Alsatian and a 'good' one? Probably, it was the big one that he really wanted" (December 11$)^{55}$.

Instead of money rapidly decreasing in value, the authors of advertisements suggested bartering pets for valuables and other sought-after things. "Once I read an ad on the post: 'Want to exchange a gold watch for a cat' " (January 1942) ${ }^{56}$. "We were offered a gold watch and a men's suit for our cat and dog, but my mother refused to give them away", recalls V. A. Oberemko ${ }^{57}$. Apart from the advertisements offering to buy cats and dogs as substitutes for food, there were also ads offering to slaughter them. In return for

48 Avgustyniuk A.I. Moi vospominaniia s momenta nachala Velikoi Otechestvennoi voiny do kontsa ee. 23 iiunia 1941 g. - 9 maia 1945 g. // CGAIPD St. Petersburg. Fond 4000. Inventory 11. File 2. P. 14.

49 Ostrovskaia Sofiia Kazimirovna. Dnevnik // OR RNB. Fond 1448. File 9. P. 125 back.

50 Konopleva Mariia Sergeevna. V blokirovannom Leningrade (1941-1942 gg.). Zametki // OR RNB. Fond 368. File 2. P. 5.

51 I. D. Zelenskaia. Dnevnik 7 iiulia 1941 g. - 6 maia 1943 g. // TsGAIPD. St. Petersburg. Fond 4000. Inventory 11. File 36. P. 46.

52 Lomagin N. A. V tiskakh goloda. Blokada Leningrada v dokumentakh germanskikh spetssluzhb i NKVD. St. Petersburg, 2014. P. 149.

53 Blokadnyi dnevnik. St. Petersburg; Tallinn, 2010. P. 176.

54 Kostrovitskaia Vera Sergeevna (1906-1979) artistka baleta, pedagog klassicheskogo tantsa. Vospominaniia o blokade // CGALI St. Petersburg. Fond 157. Inventory 1. File 28. P. 4.

55 Luknitskii P.N. Leningrad deistvuet... Frontovoi dnevnik (22 iiunia 1941 g. — mart 1942 g.). Moscow, 1961. Book 1. P. 471.

56 Lazarev D. N. Leningrad v blokade // Trudy Gosudarstvennogo muzeia istorii Sankt-Peterburga. Issue V. St. Petersburg, 2000. P.202.

57 Bol'shov V.M. Ia povedu tebia v Muzei...: 1941-1945. Ul'ianovsk, 2010. P. 130. 
the service, the 'butcher' would take his/her share of the meat. It is difficult to say how effective these advertisements were, but they undoubtedly reflected the collective idea of one of the possible methods of survival and influenced the motivation of people's actions, suggesting the survival strategies.

Some residents of the besieged city were ashamed of eating pets' meat, others, on the contrary, took pride in it. Women who proved to be tougher than men showed more tact. By contrast, men demonstrated genuine interest in the issue of eating pets and enthusiastically commented on the taste of their meat. The survivals often remembered the deceased animals which had saved their lives with gratitude. Eating meat of pets seemingly brought them back to the happy life before the war. The taste of cat and dog meat evoked memories of 'peacetime' food. As in the case of other food surrogates, people bragged about their culinary achievements (in particular, cooking brain and lever of pets, as well as making 'barbecue in Caucasian style', soup, roast and jellied meat) and compared taste qualities of cats and dogs. The diaries of citizens contain the gastronomic comments on various dishes and record the number of eaten animals. According to the people of Leningrad, eating pets at the time of famine was not only acceptable, but could be a reason for pride.

However, not all people could overcome their aversion and moral taboos. "At the end of October we got hold of a cat", narrates T. S. Fadeeva. "I cooked a roast and it must have been good enough as the family quickly polished it off. All, except me - I could not touch this food" 58 . However, sometimes the hunger pangs were unbearable: "At first I told myself over and over that I would rather die than eat cats", confesses E. Pavlova in her diary on November 6. "Now I take my words back, I would be delighted to cook and eat a cat, but there are no cats around" 59 .

"Within the period between November 15 and December 15 we ate a dog, the one which belonged to E. L. Frank and which I had thoughtlessly adopted (something I deeply regret now) and two cats $\langle\ldots\rangle$. We were so hungry that we ate this meat without the slightest bit of aversion and even enjoyed it. Unfortunately, in November and December there was no allotment of fats or cereals, so we had to eat only watery broths cooked from this meat" 60 .

The painter A.A.Griaznov, who agreed to barter 300 grams of bread for a cat, in December 1941, featured his anxiety and 'febrile state' induced by the prospect of killing a pet. Griaznov failed to find the words to describe 'the nightmare' that followed. He ate soup and meatballs, cooked from this meat, 'with disgust driven by hunger only'. The jar with the leftovers was stolen on the tram. "It looks like I am not fated to finish up the cat" ${ }^{\prime \prime 1}$.

Residents of the city often bitterly confessed that they, driven by hunger, had sacrificed their pets, and criticized the unscrupulousness of others. There were people who could afford to kill their own cat in order to cook a meal and treat the guests at the nameday party ${ }^{62}$. "Roasted cat. // And the guests, sitting at the table. // I am looking at the

58 Fadeeva T.S. Iz lichnykh vospominanii // "My znaem, chto znachit voina...": Vospominaniia, pis'ma, dnevniki universantov voennykh let. St. Petersburg, 2010. P. 142.

59 Pamiat': Pis'ma o voine i blokade. Issue 2. Leningrad, 1987. P. 190.

60 Velikotnaia T.K. Dnevnik nashei pechal'noi zhizni v 1942 g. // Chelovek v blokade. Novye svidetel'stva. St. Petersburg, 2008. P. 83, 84.

${ }^{61}$ Griaznov A. A. Dnevnik 1941-1942 gg. // Chelovek v blokade. Novye svidetel'stva. P. 60-68.

62 See: Foniakova E. Ragu iz Barsika. St. Petersburg; Moscow, 2016. P. 185. 
bread, counting the bones. // Waiting for the guests to leave"63. Speculating on what was going on, K. V.Polzikova-Rubets, a teacher, wrote a 'chapter about cats' in her diary, in which she traced the evolution of her attitude towards eating them - from resentment to expectancy ${ }^{64}$.

Pets fully depended on their owners. In the beginning the owners would usually do their best to save them but as the situation became more desperate, they would eventually bring themselves to sacrifice the pets. This decision might have been extremely traumatizing. Pondering on this many years later, owners at times felt remorse and tried to shift responsibility for the immoral act on somebody else. A war correspondent P.N. Luknitsky in his diary gave an account of how his father, who initially was indignant at the idea of eating their favorite dog, later on "found a man... [who] agreed to butcher it in exchange for the head and legs" ${ }^{35}$. N.N. Luknitsky, the father of the author, claimed that it was the children who asked to kill the dog: "At the time I did not resist the insistent demands of Pavel and especially Adia, who were starving"66. Even deep affection could not check the violence. V.N.Ge, a war veteran, in his diary refers to a "story told by one actor a wellmannered man" who, despite the affection of many years, after a long hesitation "one evening took the cat lovingly in his arms, gave it a pat and suddenly stuffed it into a bag, tied it with a rope and struck a fatal blow in the cat's head with an ax handle"67.

The tragic lot of pets might have disunited members of one family, who in their efforts to excuse themselves, mythologized the events of the past or consigned them to oblivion. Being a profoundly traumatic experience, killing of pets was at times was perceived in families as a tragic event, a disgraceful act, which had to be forgotten. "One day Father asked my sister: 'Give Pyshka (Doughnut, our white Pomeranian dog) to me, it will not survive anyway', recalls Z. Bodanova. "Nobody saw how he butchered the dog; he cooked it himself - it smelled like mutton... It became a horrible, repugnant secret, which we had to keep to ourselves as nobody would ever understand it" ${ }^{\text {"68. }}$. Another story, sad but spiritually uplifting, about a Doberman pinscher, a true friend and a member of one Leningrad family provided the framework of F. A. Abramov's short story 'Jim's descendant.' The protagonist of the story, a painter, who survived at the expense of his dog's life, 'in the last two years would hardly leave the apartment, painting the portraits of his dearest Dar again and again...'"69

\section{'Yes, they died, and it served them right'}

Citizens of the besieged city reacted differently to the infringement of traditional norms regarding the relationship of people and pets. However, one thing remained permanent -explicit emotionally-charged statements. For some people such behavior was justified and natural, others perceived it as an outrageous and senseless indulgence. The

${ }^{63}$ Gor G. Stikhotvoreniia 1942-1944. Moscow, 2012. P. 41.

${ }^{64}$ Polzikova-Rubets K. V. Dnevnik uchitelia blokadnoi shkoly (1941-1946). St. Petersburg, 2000. P. 21, 22.

${ }^{65}$ Luknitskii P. N. Leningrad deistvuet... P. 404.

${ }^{66}$ Perekrestki sudeb: Vospominaniia Luknitskikh / V. A. Luknitskii, T. E. Sokhor. Moscow, 2014. P. 167.

67 Ge V.N. Dnevnik // Leningradtsy: Blokadnye dnevniki: Iz fondov Memorial'nogo muzeia oborony i blokady Leningrada. St. Petersburg, 2014. P.219, 220.

68 Pamyat': Pis'ma o voine i blokade. Issue 1. Leningrad, 1985. P. 14.

69 Abramov F. A. Potomok Dzhima. P. 78, 79. 
latter were shell-shocked and horrified by the practive of eating pets; the former found it reasonable and envied those who had such a possibility. Those who used to eat pets could be stigmatized as social outcasts and even equated with cannibals, and their death was seen as a fair retribution. Objecting to such arguments of her friends, K. V. PolzikovaRubets made an entry in her diary: "They feed their own cat and call the people who eat cats cannibals. It makes me angry... Who, in his right mind, will feed pets under such circumstances? It is crazy to compare this to cannibalism - since we raise and eat calves, pigs and chickens. It is feeding cats that I find immoral"70.

Defenders of pets stated the opposite. "I was gobsmacked", recalls N. Moskalenko, "The people who owned cats and dogs, who loved and fed them, ended up eating them. ...A neighbor who had adored her cat and fed chocolate to her said that its meat was delicious" 71 . In summer 1942, G. N. Korneeva, a headmistress, featured her neighbor in a diary: "The eaters of cats and dogs were the first to die. These people obviously lacked self-control and by nature resembled animals rather than humans....We ...hated these cat killers as if they were our personal enemies, and did not feel sorry for them. They died, and it served them right"72.

Purebred dogs seemed to have been in a more privileged position. During the early months of the war and siege they were entitled to ration. For example, according to A. A. Griaznov, a painter, the family of his brother received some meat for the dog on 1 October $^{73}$. The report of Leningrad dog-breeding Society states that 48 tons of dog food was allocated to the society to preserve the most valuable breeds of dogs. Due to this allotment the society managed to save a number of pedigree dogs necessary for further breeding ${ }^{74}$. Dog ration sometimes could support not only dogs, but their owners as well. However, the efforts to save an Irish setter Joy, a 'family member', who received some 'flour waste' and 'horribly looking intestines', turned out to be futile ${ }^{75}$. Owners tried to sustain their pets only before the first winter of the siege, after that "dogs themselves became food"76.

In the memoirs of the siege survivors killing and eating pets appears as a mournful, but inescapable ritual. I. Korotkevich narrates: "When the dog was shot by a neighbor, as there was no food for it, the family members shedding floods of tears ate it to the last bit"77.

Killing a pet was not only a moral challenge, at times it was a physical challenge as well. The diary entries of the schoolgirl V.Peterson describe these agonizing reflections. "It was agreed to kill Silva (an Irish setter), but how?!! We suggested first hitting it on the head with a hummer and then butchering it, but it did not go according to plan....We decided to kill it for the meat, on the one hand, and because we had nothing to feed her, on the other hand"(October 15$)^{78}$. "We will have to kill Silva and salt its meat. It will last

70 Polzikova-Rubets K. V. Dnevnik uchitelia blokadnoi shkoly. P. 21.

71 Lur'e L. Ia., Maliarov L. I. Leningradskii front. St. Petersburg, 2012. P. 156.

72 Dnevnik Korneevoi Glafiry Nikolaevny, direktora shkoly No. 3 Sverdlovskogo raiona. 21 iiulia 13 oktiabria 1942 g. // TsGAIPD. St. Petersburg. Fond 4000. Inventory 11. File 51. P. 21, 21 back.

73 Griaznov A. A. Dnevnik 1941-1942 gg. P. 25.

74 Petrov-Maslakov M. A. Itogi raboty Leningradskogo obshchestva krovnogo sobakovodstva za 15 let // Okhotnich'i sobaki Leningrada (1931 - XV - 1946): Iubileinyi sbornik. Leningrad, 1947. P.41-42.

75 Dunaevskaia N. Nashe sovershennoletie: Povest' o blokade i evakuatsii. St. Petersburg, 2014. P. 11, $33,41,42$.

76 Inber V.M. Pochti tri goda. Leningradskii dnevnik. Moscow, 1968. P. 49.

77 Korotkevich L.I. Nam zhizn' dana... St. Petersburg, 2012. P. 28, 29.

78 Dnevnik Vali Peterson - uchenitsy 7 klassa 239 srednei shkoly Leningrada. 9 oktiabria 1941 6 ianvaria 1942 g. // TsGAIPD. St. Petersburg. Fond 4000. Inventory 11. File 86. P. 2, 2 back. 
us long. I am so sorry about this. I am at a loss what to do?!" (November 8 ) $^{79}$. "Somebody has stolen and eaten our poor Silva" (December 13) ${ }^{80}$. Pity, remorse and despair featured by the girl epitomize feelings of many pet owners, practices and attitudes typical of the people around her.

Eating pets could save lives, but did not guarantee survival. When a colleague of a certain T.P. Orlov came to his house after his death, she found "the room in a terrible mess... Everywhere there were traces of blood of cats and dogs caught and butchered by him, but, alas, they did not give him much strength"81. "When Ivan died, his sofa was removed, and there were twelve cat skins scattered all over the place...", the poet O. Shestinsky retells the story of one woman about her neighbor, "...However, the hunt did not help" ${ }^{2}$. "The 'rabbits' haven't helped much", recalled T. B. Bezladnova, "In spring, both Mother and Volodya died of starvation" 83 . It should be noted that in these cases the death of the people who were compelled to eat pets was not perceived as retribution, but evoked feelings of compassion and grief.

There were some people who managed to save the lives of their pets during the siege. The price of this might have been very high. Thus, I. G. Erenburg stated that of the two poodles of the writer I. A. Gruzdev, only one survived; the owner fed him on the meat of the other ${ }^{84}$. Pets were of great importance for the lonely people. Owners sustained the lives of their pets for as long as they could, and pets, in turn, became a prerequisite for the survival of their owners. The death of an owner inevitably brought about the death of a pet.

Since the spring of 1942 a number of pets dropped dramatically, and the very appearance of a cat or a dog in the streets represented an unusual sight which attracted excessive attention and sometimes aroused gastronomic interest. "I have seen a live dog at Chernyshevsky bridge, and another one also the day before. It is amazing!" 85 The children were also quite shrewd: " - - Uncle Misha! I saw a show on the Neva river yesterday...' '- What kind of show?' ' - There was a live dog running around, and nobody has eaten it yet...'”. This is the dialogue between the historian from Leningrad M. B. Rabinovitch and his seven-year-old niece ${ }^{86}$. "Once in summer I went out with my mother and saw a cat", recalls O.N. Gusiatnikova, who was a child during the war. "The first idea which came to my mind was that it was eatable" ${ }^{17}$. Such a reaction on the part of a child (as children usually demonstrate interest and friendly feelings towards pets) is evidence of the sufficient aberration from the normal perception of pets.

However, little by little the attitude towards cats and dogs started to change and returned to the model of peacetime. Few survived pets fascinated children. Adults remembered cats and dogs, but they slipped out of the memory of the little residents of the besieged city. Lack of knowledge engendered curiosity and amazement. "The children of the siege have forgotten all about cats, dogs and horses", tells O.N. Grechina, a nursery nurse,

\footnotetext{
79 Dnevnik Vali Peterson... P. 4.

80 Ibid. P. 5 back.

81 Orlova T. P. Izo dnia v den', blokadnyi dnevnik // Sever. 2000. No. 4. P. 130.

82 Shestinskii O. Angel'skoe voinstvo // Neva. 1999. No. 1. P. 80.

83 Deti voiny... P. 28.

84 Frezinskii B. Ia. Sud'by Serapionov: (Portrety i siuzhety). St. Petersburg, 2003. P. 62.

85 Boldyrev A. N. Osadnaia Zapis': Blokadnyi dnevnik. St. Petersburg, 1998. P. 213.

86 Rabinovich M. B. Vospominaniia dolgoi zhizni. St. Petersburg, 1996. P. 207.

87 Gusiatnikova O. N. Golod zabral vsiu moiu sem'iu // Blokada Leningrada: narodnaia kniga pamiati.
} Moscow, 2014. P. 175. 
about the spring of 1943. " $<\ldots>$ The children enthusiastically exchanged stories about the pets they had kept before the war, and these stories sounded like fairy-tales" 88 .

Pets fascinated children and moved the hearts of adults. "There is a fat ginger cat walking safely in canteen No. 100, and nobody makes an attempt on its life..." wrote M.S. Konopleva on January 1, $1943^{89}$. For the residents of Leningrad it symbolized the near end of the siege and war, and the forthcoming peace. There were other signs of these future changes as well: adults weeping over the loss of their loved ones; boys,scuffling in the streets. "Pigeons have reappeared in Leningrad. Superstitious people claim that this is a good omen, and peace is just around the corner", wrote S. K. Ostrovskaia on July 4, 1943. " $<\ldots>$ I have no fancy for pigeons. It is a cat I would like to see - an ordinary, typically Russian stray cat walking across the street in a businesslike manner or blinking at the sun, looking out of the cellar. Then I will believe that everything is going to be fine, and the hunger and siege are over"

Most of the residents could not afford to get a pet. Cats disappeared. Meanwhile the city needed them urgently, in particular, the people working with food supplies and other goods. Thus, the director of the Frunzensky chain of shops K. F. Aleksandrov announced at the party meeting in December 1942: "Combating rodents has proved to be unsuccessful; they damage the goods, and the losses at times are bigger than the rules allow us to have. Every store needs a cat. It will help to avoid the damage of goods and sack tare"91. "I have seen an advertisement on the door of the bakery with my own eyes: 'We would like to buy a cat for 200 rubles', narrates O. Grechina, "At that time it was the price of four kilos of bread. A real fortune! The shop assistants, though, never got the cat they asked for" However, other shops must have managed to purchase the animals they needed: "We have traded our Angora cat for a loaf of white bread at the bakery", reports L. P. Romashov ${ }^{93}$. "My mother gave out a dog for a loaf of bread to the food storehouse located on our street", recalls T. P. Tishchenko ${ }^{94}$.

Not only the shopping centers, but ordinary people as well started to take interest in pets in the way it used to be before the siege. However, taking into consideration the lack of pets, the price of them escalated. "A kitten costs 700-800 rubles", wrote in his diary A. N. Boldyrev on June 23, $1943^{95}$. The writer A. I. Panteleev claimed in January 1944: "A kitten in Leningrad costs 500 rubles" ${ }^{\prime \prime 6}$. Some decrease in the price of pets after the hardest period in the siege apparently indicates a gradual increase in their number in the city.

The urgent need to control rodent pests and the desire of many residents to get pets gave rise to a widespread legend, deeply-rooted in collective consciousness and widely

${ }^{88}$ Grechina O. Spasaius' spasaia: v 2 ch. Ch. 2: Skazka o gorokhovom dereve (1942-1944 gg.) // Neva. 1994. No. 2. P. 220.

${ }^{89}$ Konopleva Mariia Sergeevna. V blokirovannom Leningrade (1941-1942 gg.). Zametki // OR RNB. Fond 368. File 3. P. 18.

90 Ostrovskaia Sofiia Kazimirovna. Dnevnik // OR RNB. Fond. 1448. File. 15. P. 112.

${ }^{91}$ Partorganizatsiia Frunzenskogo raipishchetorga // TsGAIPD. St. Petersburg. Fond 635. Inventory 1. File 5. P. 80.

92 Grechina O. Spasaius' spasaia... P. 220.

93 Iurovskii E. M. My vyzhili v blokadu! St. Petersburg, 2004. P. 149.

94 Tishchenko T.P. Liudi umirali spokoino, bez krika i stona // Blokada Leningrada: narodnaia kniga pamiati. P. 676.

${ }_{95}$ Boldyrev A. N. Osadnaia Zapis'... P. 291.

${ }^{96}$ Panteleev A. I. Zhivye pamiatniki: Rasskazy. Putevye zametki. Dnevniki. Vospominaniia. Moscow; Leningrad, 1967. P.229. 
covered by the press, about the delivery of carriages and even trains with cats caught in the east of the country to Leningrad. The myth of the cats from Yaroslavl', Krasnoyarsk and Tyumen, which is persistent even now, has no historical confirmation. The authors of this article have not found any official documents about this event. It is more likely that the cats came to Leningrad from other sources, in particular, from the suburbs, where more food was available, and the conditions were more favorable for reproduction.

At the same time the persistence of the legend about the organized delivery of a great number of cats to Leningrad, similar to the idea of the abundant supplies of foodstuffs burnt in the fire during the bombing of the Badaevsky warehouses, and unexploded German blockbuster bombs, stuffed with granulated sugar and kerf waste, is related to the desire of many siege survivors to interpret the horror they have been through and deal with the trauma of the siege. The 'feline' legend reflected the need to conceive the inconceivable: mass death of people from starvation, the consumption of unthinkable food surrogates, including pets. This myth sustained by many siege survivors implied their eagerness to overcome the shock and to seek the forgiveness of the dead. The popularity of the myth about the delivery of cats to Leningrad, and of the rumors about the great variety of foodstuffs ready to surge into the hunger-wearied city and about the facilities in sanatoria and health resorts for residents, reflected the excessive eagerness of the people of Leningrad to feel that they were not forgotten, and that the country wanted to come to their aid ${ }^{97}$. These dreams to return to the happy times before the siege, with the cats whose lives were in no danger, helped to endure the hardships and to last out till the end of the siege.

\section{'A unique rarity - a dog'}

It seems difficult to estimate how many pets had survived in besieged Leningrad. In January 1944, A. I. Panteleev wrote: "Dogs have become a unique rarity in Leningrad"98. By rough calculation, we can say that during the siege of Leningrad approximately 700 of purebred hunting dogs registered on the books of the local dog-breeding society died ${ }^{99}$. About 50 dogs survived. In June 1944, 8 Eskimo dogs, 6 hounds, 2 pointers, 3 Irish setters, 11 Gordon setters, 3 Dachshunds, 1 fox-terrier and 5 housedogs were demonstrated at the local exhibition of hunting dogs ${ }^{100}$. It was from these few dogs who survived the siege that the recovery of hunting dogs in the city began. The guard dogs of the $34^{\text {th }}$ mine-search battalion also had pulled through. Moreover, 5 Alsatians worked for the police (militia) ${ }^{101}$. Apart from guard and hunting dogs spared from death, there must have been some mongrel dogs that managed to survive due to their owners. I. G. Erenburg, who happened to visit the exhibition, wrote: "There were about 15 dogs that outlived the siege - little skinny mongrels. They were held by their owners, small, emaciated old ladies who had shared their scanty rations with the pets"102. Paradoxically, pets in the besieged city not only died but proliferated as well, although such cases undoubtedly were few and far between.

97 Piankevich V.L. "Liudi zhili slukhami". Neformal'noe kommunikativnoe prostranstvo blokadnogo Leningrada. St. Petersburg, 2014. P.348-382.

98 Panteleev A.I. Zhivye pamiatniki... P. 232.

99 Petrov-Maslakov M. A. Itogi raboty Leningradskogo obshchestva... P. 42.

100 Ibid.

101 Messer R. Militsiia osazhdennogo goroda. Leningrad, 1945. P. 41-46.

102 Erenburg I. Liudi, gody, zhizn': v 3 tomakh. Moscow, 2005. Tom 3. Books 6, 7. P.9-10. 
During the war family bonds grew stronger. The affection for pets also deepened. However, when the hardships of the siege, the fear of death caused by starvation, the cold, bombing and shelling and psycho-emotional stress exasperated the people, they sometimes violated conventional ethical norms regarding not only pets, but their family members as well ${ }^{103}$.

During the siege of Leningrad, when hundreds of people starved to death, the conventional norms came to naught ${ }^{104}$, and the idea that animals also had the right to live was in the eyes of many residents nothing more than a fancy. At the time when many people lacked physical and moral strength to save their loved ones, it would require high moral standards to share one's food with pets.

Gastronomic interest in pets was a strange perversion for a European city. Nevertheless, under the threat of starvation, some people viewed the perspective of eating cats and dogs as a reasonable way of survival. "Cats or dogs cannot be found anywhere in Leningrad nowadays. To be honest, we have not tasted them yet, not because of being squeamish, but because we failed to catch any of them" (January 7, 1942) ${ }^{105}$. The willingness of many residents to eat pets can be confirmed by the statement of one woman memorized by her son: "After the war people kept asking my mother: 'Did you feed cats and dogs to your children?' And she would answer: 'Probably, I would have done so if I had had the opportunity to get them'"'106.

At the same time some people might have felt both deep gratitude and great remorse for their actions. The actress E. F. Anderegg gave an account of the scene which she witnessed in 1945 at the end of the war: a woman was kneeling in front of the stray cats asking to forgive her "for killing them in order to feed her starving children - the children survived the siege" 107 .

At the expense of the life of a pet some people could prolong their existence and even escape death. Racked by remorse, many starving residents of Leningrad did not see another way out but to kill and eat pets. Their compatriots demonstrated different attitudes: some of them did not see anything disgraceful in this and sought ways of buying, trading, badgering the owners to sell a pet or catching a cat or a dog, and used to eat their own pets. For others, it was a drastic means of survival; they sympathized with cat-eaters, and after agonizing soul-searching and a great deal of reluctance sometimes brought themselves to kill their pets. Finally, there was a group of people who rejected this practice vigorously; they would have rather died than betray their pets. These people despised those who ate pets, compared them to cannibals and perceived their death as retribution. Thus, it can be claimed that the attitude towards eating pets was not entirely negative. Moreover, most of the siege survivors were inclined to understand their compatriots and justify their decision to escape death at the expense of the pets' lives.

${ }^{103}$ Piankevich V.L. The Family under Siege: Leningrad, 1941-44 // Russian Review 2016. Vol.75. No. 1. P.107-137.

104 See: Iarov S. V. Blokadnaia etika: predstavleniia o morali v Leningrade v 1941-1942 gg. Moscow; St. Petersburg, 2012.

105 Skriabina E. A. Stranitsy zhizni. Moscow, 1994. P. 136.

106 Glushchenko Iu. Evakuatsiia prevratilas' v okkupatsiiu // My iz blokady: Sbornik vospominanii. Kirov, 2003. P.75.

107 Ispytanie: vospominaniia nastoiatelia i prikhozhan Kniaz'-Vladimirskogo sobora v SanktPeterburge o Velikoi Otechestvennoi voine 1941-1945 godov. St. Petersburg, 2010. P. 109. 
The attitude of a person to pets is modeled on his / her attitude to other people, society and the world and reflects the essential features of this person's character. The treatment of animals was indicative of moral losses suffered by some residents of the city. Cats and dogs of Leningrad did their duty of devoted companions of the people, reassuring them, providing consolation, rejoicing their hearts and never displaying aggression. At the same time, the death of a pet deprived people of the sense of safety, of the possibility to take care of somebody, and at times made their life aimless, remaining a deeply traumatic reminiscence.

\section{References}

Bobyr' S. L. The System of Military Dog Breeding in the Great Patriotic War. 1941-1945: Historical Aspect. Dysha odnim dykhan'em: Voennye kinologi na fronte. St. Petersburg, 2015, 270 p. (In Russian)

Dzeniskevich A. R. Banditry (a Special Category) in Besieged Leningrad. Istoriia Peterburga, 2001, no. 1, pp. 47-51. (In Russian)

Dzeniskevich A. R., Koval'chuk V. M., Sobolev G. L., Tsamutali A. N., Shishkin V. A. Unconquered Leningrad: A brief Outline of the History of the City During the Great Patriotic War. Leningrad, Nauka Publ., 1970, 414 p. (In Russian)

Kovalchuk V.M., Rupasov A.I., Chistikov A.N. Leningraders During the War: Adaptation Practices. Adaptatsiia narodov $i$ kul'tur $k$ izmeneniiam prirodnoi sredy, sotsial'nym $i$ tekhnogennym transformatsiiam. Ed. by A.P. Derevyanko. Moscow, ROSSPEN Publ., 2010, pp. 380-387. (In Russian)

Lazarev D. N. Leningrad in Blockade. Trudy Gosudarstvennogo Muzeia Istorii Sankt-Peterburga. Iss. V: Materialy k istorii blokady Leningrada. Ed. by V. A. Frolov. St. Petersburg, State Museum of the History of St. Petersburg Publ., 2000, pp. 192-241. (In Russian)

Lomagin N.A. In the Grip of Hunger. The Blockade of Leningrad in the Documents of the German Special Services and the NKVD. St. Petersburg, Avrora-Dizain Publ., 2014, 360 p. (In Russian)

Lur'e L. Ya., Malyarov L. I. Leningrad Front. St. Petersburg, BHV-Petersburg Publ., 2012, 272 p. (In Russian)

Petrov-Maslakov M. A. The Results of the Work of the Leningrad Society of Blooded Dog Breeding for 15 Years. Okhotnich'i sobaki Leningrada (1931-XV - 1946): Iubileinyi sbornik. Leningrad, Publishing House of the Leningrad Regional Society of Blood Dog, 1947, pp. 5-44. (In Russian)

Piankevich V.L. "People Lived by Rumors". Informal Communicative Space of the Besieged Leningrad. St. Petersburg, Vladimir Dal' Publ., 2014, 478 p. (In Russian)

Piankevich V.L. The behavior of Leningraders on the eve and at the beginning of the blockade. Velikaia Otechestvennaia voina: pravda i vymysel: Sb. statei i vospominanii. Iss. 7. Ed. by V.A. Kutuzov. St. Petersburg, St. Petersburg Uniiversity Press, 2012, pp. 36-90. (In Russian)

Piankevich V.L. The Family under Siege: Leningrad, 1941-44. Russian Review, 2016, vol. 75, iss. 1, pp. 107137.

Sokolov A. M. The Battle for Leningrad and its Significance in the Great Patriotic War. St. Petersburg, Asterion Publ., 2005, 340 p. (In Russian)

Yarov S.V. "Blockade’s Cookbook". SSSR vo Vtoroi mirovoi voine: okkupatsiia, kholokost, stalinizm. Eds O. Budnitskii, L. Novikova. Moscow, ROSSPEN Publ., 2014, pp. 250-266. (In Russian)

Yarov S. V. Blockade Ethics: Ideas About Morality in Leningrad in 1941-1942. Moscow, St. Petersburg, Tsentrpoligraf Publ., 2012, 602 p. (In Russian)

Статья поступила в редакцию 8 мая 2019 г. Рекомендована в печать 2 декабря 2019 г.

Received: May 8, 2019

Accepted: December 2, 2019 